\title{
From Darwin's On the Origin of Species by Means of Natural Selection... to The evolution of Life with Communication Activity as its Very Essence and Driving Force (= Mega-Evolution) ${ }^{1}$
}

\begin{abstract}
Arnold De Loof ${ }^{2}$
Abstract: Darwin's theory of evolution with focus on the origin of new species was formulated in an era in which the principles of genetics, biochemistry, physiology, communication etc. were not an issue. Numerous revolutionary new insights have since been gained. 1. The 'sender-receiver communicating compartment", a classical but still valuable concept, is better suited than 'the cell' to serve the role of universal unit of structure and function, 'the cell' being the smallest such unit; 2 . Not only genetic, but non-genetic mechanisms as well contribute to variability that can be passed onto the next generation; 3. Natural selection, the almost unanimously accepted universal driving force of evolution, is itself the result of preceding problem-solving activity enabled by the principles of communication; 4. A logically deduced, unambiguous definition of 'Life' has been published so that now the key question can shift from Darwin's formulation towards "How does 'Life', with its many aspects, change in the course of time"? Communication activity represents the very heart of being alive, thus of 'Life itself'. In digital-era wording, living entities are hardware-software double continua. This paper advances an easily teachable change in paradigm, namely that evolution concerns ever changing complexes of signalling pathways, chemical and other, that occasionally yield both new species and additional (at least 16) levels of communication. This approach complements the genetic basis of the New Synthesis with several as yet undervalued mechanisms from physiology and development. In particular, 'the universal selfgenerated electrical dimension of cells' and Lamarckism deserve an upgrade.
\end{abstract}

Key Words: Evolution, development, evo-devo, New Synthesis, Extended New Synthesis, ENS, EES, Calcigender, definition of Life, Metadarwinism

\section{Introduction}

In future accounts of the history of biology the beginning of the 21th century may be marked as an era in which the neo-Darwinian approach to evolutionary theory, known as The New Synthesis (NS, Mayr 1993, Gould 2002, for a brief conceptual history of evolutionary theory, see Pigliucci 2007) faced increased opposition to some of its very foundations. The principle of common descent is not questioned; to the contrary it has never been better

\footnotetext{
${ }^{1}$ Received on September 7, 2015. Accepted on September 19, 2015. Last revisions received on October 12, 2015.

${ }^{2}$ Functional Genomics and Proteomics Group, Department of Biology, KU Leuven, University of Leuven, Belgium. Address: Zoological Institute, Naamsestraat 59, 3000 Leuven, Belgium. E-mail: arnold.deloof@bio.kuleuven.be
}

DOI: 10.9784/LEB3(3)DeLoof.01

Electronically available on October 31, 2015. Mailed on October 27, 2015. 
documented (Ruggiero et al. 2015) and it is generally accepted. Part of the intensifying discomfort with the New Synthesis originates from the continuing attempts by some neo-Darwinists to force as many as possible causes of variability that are instrumental to evolutionary change into the straitjacket of inheritance/genetics, while for some aspects (e.g. cultural evolution) the term 'transferability of information to the next generation' is more appropriate. A typical example is the "inclusive approach" (Danchin et al. 2011) in which there is no role for a cognitive memory system different from the genetic memory (DNA $\rightarrow$ RNA $\rightarrow$ proteins). In particular, for physiologists it is unacceptable that such approach continues to ignore, despite all experimental evidence, that the cytoplasmic inorganic ionic environment $\left(\mathrm{H}^{+}, \mathrm{K}^{+}, \mathrm{Na}^{+}, \mathrm{Ca}^{2+}, \mathrm{Cl}^{-}, \mathrm{HCO}_{3}{ }^{-}\right)$ with its numerous functions, action potentials and control of gene expression as major examples, is not (fully) controlled by the central dogma (Crick 1970). Neither can it in full explain the role of lipids and of the cytoskeleton and the growing evidence that species can, to some extent, direct their own evolution (Pookottil 2013).

Not only physiologists but some evolutionary biologists, geneticists, and researchers in other disciplines, the humanities inclusive, also advanced arguments for developing an upgrade or extension of the New Synthesis (Stebbins and Ayala 1981; Shapiro 2011; Noble 2008, 2013, 2015; De Loof 2002, 2015; Pigliucci, 2007; Pigliucci and Muller, 2011; Baluska, 2011; Baluska and Witzany 2013; Jablonka and Lamb 2014; Kull and Emmeche 2011; Danchin and Pocheville 2014, and others). On the website named The Third Way. Evolution in the Era of Genomics and Epigenomics (http://www.thethirdwayofevolution.com/), the discomfort with the classical genetics-approach is worded as follows: "Neo Darwinism ignores much contemporary molecular evidence and invokes a set of unsupported assumptions about the accidental nature of hereditary variation. It ignores important rapid evolutionary processes such as symbiogenesis, horizontal gene transfer, action of mobile DNA and epigenetic modifications. Moreover, some neo-Darwinists have elevated Natural Selection into a unique creative force that solves all the difficult evolutionary problems without a real empirical basis."

This list needs several more additions. The humanities and the engineering sciences need another approach than a purely genetic one to frame their insights in the role of the cognitive memory, of non-chemical languages, of semiotics and of intelligence and consciousness in the mainstream of evolutionary theory (Eco 1978, Westling 2014, Kull and Emmeche 2011, Trewanas and Baluska 2011, Wheeler 2006, Jablonka and Lamb 2014, and others). Why do many evolutionary theorists walk, with eyes averted, in a wide arc around the most fundamental problem of all, namely that one should first define the subject of which one intends to study the evolution, namely Life itself, before engaging in the analysis of the mechanisms instrumental to its variability? Yet, the obstacle, namely that "defining Life is thought to be impossible because 'Life' is too 
complex to be worded in a single sentence" (Raven et al. 2014), does no longer exist. Indeed, a logically deduced unambiguous definition of Life was already published some 20 years ago (De Loof and Vanden Broeck 1996) and recently revived (De Loof 2015). Also, the question how problem-solving is instrumental to adaptation needs a physiology-based answer. Next, it can be confronted with "Natural Selection as driving force of evolution ".

The cited shortcomings in the New Synthesis (NS) are not recent. For decades already it has been argued that there is need for an upgraded or Extended New Synthesis (ENS, also abbreviated as EES by Laland et al., 2014) (Stebbins and Ayala 1981; Mayr 1993; De Loof 2002; Muller and Newman 2003; Pigliucci 2007; Heams et al. 2009; Sapp 2009; Pigliucci and Muller, 2011; Laland et al. 2014; Jablonka et al. 2014; Baluska 2011; Bauer 2012; Koonin 2012; Shapiro 2011, 2012; Pookottil 2013; Benneth 2014; Walsh 2015, and others), be it that not everybody is convinced that an upgrade should best be started from a new paradigm.

Any emerging ENS should be compatible with an unambiguous definition of Life, it should take into account that living systems have two memory systems (genetic- and cognitive), and that cells have two major mechanisms of control of gene expression (coarse control by inorganic ions as well as fine tuning by, for instance, transcription factors). The ENS should not only include mutations as genetic causes of variability but all sources of variability in signalling systems. In particular, non-genetic ones, such as behaviour and symbiosis, need more attention from an evolutionary perspective. That ENS should also reconsider Natural Selection as the universal driving force of evolution and answer the question whether Selection is itself the result of some preceding activity. Finally, the ENS should take into account the growing evidence that species can, to some extent direct their own evolution. This list is not exhaustive.

At first glance, "solving this puzzle" within "normal science" (= the definition of a novel paradigm, Pigliucci 2007) may seem hardly possible. Yet, if one accepts that an all-round theory of evolution of 'Life' should start from an unambiguous definition of Life (available since 1995 De Loof and Vanden Broeck 1996, De Loof 2015), it can be done. The condition is that one agrees upon the formulation of such definition and that one accepts that the senderreceiver communicating compartment is better suited than the cell for serving as the universal unit of structure and function for all living systems (De Loof 2014).

This paper aims at showing that the novel paradigm, namely that evolution of Life is better addressed from the principles of communication rather than from those of molecular and population genetics, is supported by (undervalued) key principles of cell- and organismal physiology. No doubt, they have to fit in a holistic, universal principle. The innovative approaches (e.g. with respect to semiotics) in the humanities, as well as those in the information sciences and 
engineering have already been dealt with by authors specialized in these disciplines.

\section{A pertinent question}

Was Darwin's (1859) wording so brilliant that to date, some 155 years later it continues to be sufficiently adequate for explaining the evolution of 'Life'? Or does the enormous wealth of novel insights in biology gathered in the recent century urge for a substantial upgrade? In the latter case, if the additions that have already been suggested and/or already made to the NS without changing the essence of the current NS paradigm start losing coherence, which novel framework can explain both the facts that were explained by the previous paradigm (The New Synthesis) as well as the 'anomalies' that led to the current discomfort in the first place?

In this paper I will argue that, in my opinion, it reads: "The verb 'Life' is in fact a synonym for communication/problem-solving activity, and its evolution concerns ever changing complexes of signalling pathways, chemical and other, that occasionally yield new species and additional levels of communicational compartmentalization".

\section{Problematic issues in contemporary biology}

To better understand the causes of the discomfort with the New Synthesis as worded by an increasing number of scientists, it may not be superfluous to critically evaluate the dominant trends in biological research and thinking during the past decades of which some were causal to this discomfort. Some basic questions remain unanswered. Others have been adequately answered but the answers did insufficiently reach the mainstream of evolutionary theory. In this context, some important scientific developments that shaped the environment of ideas in the second half of the $20^{\text {th }}$ century are, as follows:

a. Numerous new research disciplines, each with a specific vocabulary came into existence. Reductionist experimentation became the leading philosophy. Formulating and teaching unifying holistic principles became more and more difficult.

b. Molecular biology/genetics flourished almost exponentially, resulting in the $20^{\text {th }}$ century having been named the century of the gene (Fox Keller 2002) and the New Synthesis a theory of genes, not a theory of forms (Karl Popper, fide Pugliucci 2007, Niemann 2014) and certainly not of functions (De Loof 2002). Many students were hardly taught to look outside the nucleus, i.e., they focused on DNA while having no interest in the possible function(s) of the proteins derived from it. 
c. Electrophysiology applied to intact cells, patch clamp applied to membrane fragments, both essential technologies for studying the 'electrical dimension of cells' (see later) as well as the holistic 'The cell as a miniature electrophoresis chamber concept' (De Loof 1986) gained less territory.

d. The disinterest in engaging in answering the undoubtedly difficult question "What is Life?" is largely responsible for the unmistakable fact that Biology continues to miss a central integrating principle. As a consequence it is perceived by the general public rather as a collection of interesting facts and stories than as a hard exact science like physics or chemistry.

e. Likewise, hardly any effort has been put in answering: "What exactly changes at the very moment of death?" Yet, answering this question yielded the key for answering "What is Life?" and how the numerous $(\geq 16)$ levels of compartmental/communicational organization of living matter can be logically categorized (De Loof and Vanden Broeck 1996) (see later).

f. The term 'communication' is frequently used in both daily- and scientific language. This contrasts with the fact that it is not common practice of textbooks of general biology to explain what communication, one of the most obvious activities of living matter, is. The reason is that because we continuously engage ourselves in communication activity, we automatically assume that we understand its principles "because of self-evident". Yet, handling information (= communication) is far from self-evident or simple. Evolution cannot be properly understood if the principles of biocommunication are insufficiently taken into account (Eco 1978; Logan 2007; Witzany 2010; Torday and Rehan 2012; Torday 2013, 2014; Westling 2013).

g. One of the largest remaining problems of all in biology is our continuing inability to uncover the basic molecular mechanisms underlying the cognitive memory. It can be logically deduced that this system must have come into existence at the very moment that Life originated. Bacteria can learn (Shapiro 2007), suggesting that the basic principles of the cognitive memory and learning, which are instrumental to problem-solving, adaptation and cultural evolution, are omnipresent in nature. It is not because its modus operandi remains enigmatic that the cognitive memory should not be taken into account in evolutionary theory. Some partial answers to these challenges can be found today in the modern theory of neural networks (Pescianschi 2015, Pescianschi et al. 2015). 


\section{Towards a substantial upgrade of the neo-Darwinian New Synthesis: Partial rewording of the essence of evolution}

\section{The starting point of the novel paradigm: The very essence of ' $L i f e$ '}

Living matter is invariably organized in sender-receiver compartments that incessantly handle information (= communicate), thereby solving problems, most of them in an automated way. The compartments incessantly change in the short run (= development) and the long(er) run (= evolution) through geneticand/or non-genetic mechanisms. They have two memory systems, a well documented genetic memory and an as yet poorly understood cognitive memory. They can transfer information to the next generation(s) (= reproduce) in various ways. Because of their architecture as sender-receivers, they can to some extent direct their own evolution.

\section{The Common Descent principle, reproduction and development}

This key principle of Darwinism does not need an upgrade, because it has been proven to be correct. It remains fully valid in our Mega-Evolution- or "Hardware-Software theory of evolution" (De Loof 2002, and this paper). Since Darwin the various modes of reproduction, horizontal gene transfer (Boekels Hogarten et al. 2009; Shapiro 2011, 2012; Noble 2015), and asexual and sexual reproduction have been intensively studied and their contributions to generating genetic variability (by meiotic recombination and hybridization e.g.) became well documented. With respect to cultural evolution, teaching-learning has been advanced as reproduction the software way (Lamarckian in nature, De Loof 2014). The methods of molecular genetics substantially contributed to understanding development and its importance for evolution (West Eberhard 2003, Wolpert et al. 2015, Gilbert 2013, Moore 2015, Müller and Newman 2003). Haeckel's 'Law' (1868) "Ontogeny recapitulates phylogeny" was a true hallmark in innovative thinking in biology. It was based on morphological observations of embryos. In recent decades it has become apparent that key developmental signalling pathways are very well conserved among animals and plants. Hence they must be evolutionarily very ancient and must have been present in the common ancestor of animals and plants. They may have been derived from unicellular organisms, as exemplified by slimemolds that communicate with each other by extracellular release of (the later intracellular messenger) cAMP, shedding light on the development of multicellular organisms using both first (extracellular) and second (intracellular) messenger systems. Haeckel's 'law' although sometimes criticized and discredited, keeps its merits.

Although the molecular genetics foundations of development in both animals and plants became very well documented, a triumph for biology, authors of textbooks seem to refrain from formulating holistic principles with respect to embryonic development. This is an example of the antagonism 
between producing huge numbers of reductionist experimental data and formulating out of them a holistic principle. Yet, such (in fact rather simple) principle can be advanced (see section 8.5).

\section{The architecture of the system that enables handling of information}

3.1. Sender-receiver. As outlined in detail before, all living matter is invariably organized in entities organized as sender-receivers (Figure 1A1) (De Loof and Vanden Broeck 1996; De Loof, 2014, 2015b). This is a classical concept, nowadays by some specialists considered as somewhat outdated and in need of rewording in the more complicated wording of biocommunication (Witzany 2010). Because everybody understands its meaning and because it is applicable to any level of compartmental organization, I stick to this classical concept.

Handling of information, the key activity of sender-receivers for deciphering sign-mediated interactions can be better described in computer-era terminology than in classical biology: see Fig $1 \mathrm{~A} 3$ for the modern version of Koshland's (2002) 'The temple of Life'. This temple has four pillars: hardware, software, energy and motivation. Communication activity is enabled by the concerted interplay between the four pillars. All pillars are subject to change in the course of time but not all four are fully controlled by genes. In the terminology of the late Robert Rosen (1991) who rejected that Life is a machine; 'Life' is indeed not a machine. In my wording, it is the activity of a special sort of machine, namely of a sender-receiver or communicating compartment. Life is not merely the sum of all its constituent parts of a functioning sender-receiver (as a machine), but the activity that results from the interaction among all its parts. The main reason(s) why a computer, a man-made mechanical extension of our brain, is not alive is that the fourth pillar of Life, namely 'motivation' (Fig. 1 A3) is (still) missing. This has been outlined before (De Loof, 2012, 2015b).

3.2. Hardware and software: Two memory systems: genetic and cognitive. Energy, Motivation. Sender-receivers require two memory systems. The principles of the genetic memory are well described in the central dogma (Crick, 1970) and many more details have been documented more recently. These will not be dealt with here. 


\begin{tabular}{|c|c|}
\hline \multicolumn{2}{|c|}{ LIFE'S NATURE } \\
\hline \hline $\begin{array}{c}\text { Essence } \\
\text { and } \\
\text { Definition }\end{array}$ & Communication Activity $\left\{\begin{array}{l}\text { Signalling pathways } \\
\text { Languages }\end{array}\right.$ \\
\hline \hline
\end{tabular}

A Principles of communication

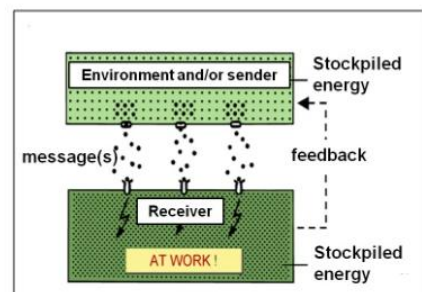

Any act of communication 1 involves problem-solving activity
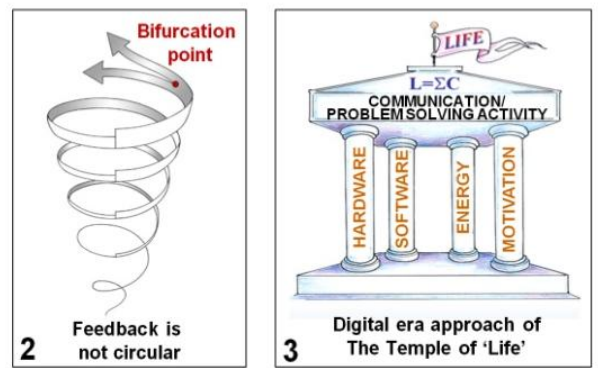

3

\section{Living systems are hardware-software double continua}

B Cellular architecture and key physiology

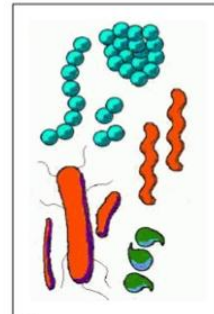

1 Prokaryotes

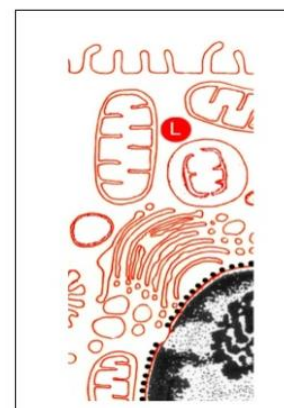

4 Lipid membranes
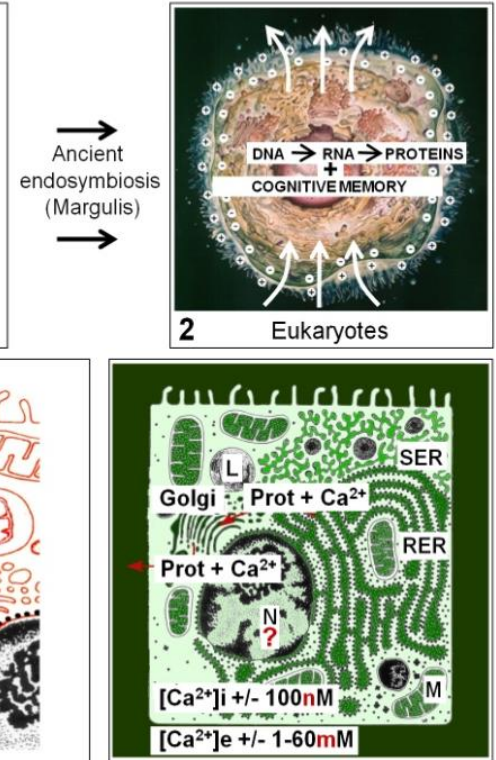

5
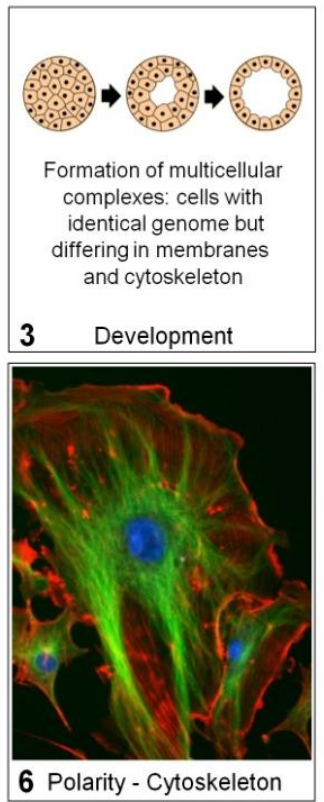

"The cell as a miniature electrophoresis chamber concept" 
With respect to the cognitive memory, it can be logically deduced that a message can only be decoded by a receiver if the needed decoding program had been installed before the arrival of the message. This must already have been the situation when the first cell on earth started functioning (De Loof 1993a). This raises questions about the mechanisms for installing such programs in the cell. Despite all progress, in particular in neurobiology, the cognitive memory remains a black box, in particular since the idea that in the model marine mollusc Aplysia stable synapses store long-term memories has been experimentally challenged (Chen et al. 2014). The fact that the cognitive memory system is very fast, electric events must play a crucial role. How can cognitive information be stored for long periods? Nobody knows. One can make some suggestions. The ideal situation would be that cognitive information can be stored lifelong. That likely requires a material storage system that lasts lifelong. DNA as carrier of cognitive information might be one possibility. But such system should not act through protein synthesis (the central dogma) because it is too slow. Perhaps some proteins may be synthesized very fast, e.g. within minutes, but this process usually takes longer. Moreover, posttranslational RNA processing might play a role, including microRNA's (Peixoto et al. 2015).

Figure 1. 'Life' can be unambiguously defined using the principles of communication. The classical 'sender-receiver compartment' (A1) is a better alternative than 'the cell' for functioning as the universal unit of structure and function of all living matter. Feedback is a spiral-like, unidirectional process (A2). At bifurcation points, a choice has to be made as to how to proceed with communication. In digital era wording, the classical 7-pillars Temple of Life (PICERAS as originally conceived by Koshland (2002) has 4 pillars (A3) that, in concert, enable communication- and problem-solving activity, the two key activities in which living systems differ from non-living ones. In the evolution of communication activity (B), several revolutions took place. A truly major one was the formation, by endosymbiosis, of the eukaryotic cell out of several prokaryotes (B1-B2) as first outlined by Lynn Margulis (1981). Another important one was the 'invention' of multicellularity and differentiation into different cell types, all with the same genome but differing in membrane-cytoskeletal properties (B3). In classical evolutionary theory (New Synthesis), with its focus on genetic mechanisms, the 'self-generated electrical dimension of cells' is undervalued. The lipid nature of cell membranes (B4) makes them good insulators for cellular electricity and for intracellular ionic compartmentalization. This type of electricity is carried by inorganic ions and not by electrons. $\mathrm{Ca}^{2+}$-homeostasis (B2) plays a prominent role in cellular physiology. Its roles have been acquired during evolution as a means to cope with its toxicity. Transcellular ionic currents are very common. A prerequisite for such currents is that cells are not spherically symmetrical but polarized. The cytoskeleton (B6) enables such architecture. A1-A3: adapted from De Loof (2002). B1, B3 and B6: adapted from Wikipedia and/or Google pictures, with thanks to the anonymous authors. B5 from De Loof (2014). 
The other long lasting molecules in cells are the ones that are structurally associated with DNA. In eukaryotes that would be the chromosomal skeleton. Here actin is a major component. Prokaryotes have actin-like molecules. Actin is a universal molecule in all cell types. In addition to its role in the cytoskeleton for providing form to cells, it can also conduct cellular electricity (carried by inorganic ions) in a very special way. Lin and Cantiello (1993) suggested a mechanism for transport of electricity from the cell periphery (the plasma membrane) into the nucleus through current transport along the actin threads, even in a medium containing inorganic ions. To my knowledge, this system, although conceptually attractive has not been further explored.

Because 'Life' is an activity, it requires energy. Alterations in the type and quality of food or preference of the 'eaters' can cause shifts in populations. Motivation: Why do organisms solve problems? Their '(active or passive) drive or motivation' is to reach physiological and psychological (if relevant) equilibrium (De Loof 2002, 2015).

\section{Definitions of Life, Death and Information: undervalued in the New Synthesis}

Hitherto it was not an issue in evolutionary theory to first define 'Life' and next ask the question which parameters can be instrumental to make Life change. But with some logical thinking, it is very well possible to formulate an unambiguous definition of Life. My strategy was to first analyze what exactly changes at the very moment of 'death' and next logically deduce the very essence of 'being alive' (De Loof and Vanden Broeck 1996, De Loof 2002, 2015b).

The common denominator in the death of a bacterium, a eukaryotic cell, a multicellular organism, a population and all other levels of compartmental organization turned out to be: "Death ensues at the very moment that a given sender-receiver compartment irreversibly (to exclude regeneration) loses its ability to communicate ( $=$ handle information) at its highest level of compartmental organization. What happens at lower levels (if present) is irrelevant (De Loof and Vanden Broeck 1986; De Loof 2002, 2015). Because 'no longer alive' or 'dead' is the genuine opposite of 'still alive', it follows that communication activity should represent the very heart of 'Life'. Communication is an exclusive activity of entities organized as sender-receiver compartments.

The following definition that meets all necessary criteria a good definition of Life should meet, according to Schejter and Agassi (1994), resulted from further logical deductions.

'Life' sounds like a noun, but it is an activity, thus a verb. It is nothing else than the total sum of all acts of communication that are executed, at moment $t$, by entities organized as sender-receivers at all their levels of compartmental organization". There are at least 16 possible levels of compartmental 
organization (for details see De Loof 2002, 2015), thus many more than the 5 or 6 that Introductory textbooks of Biology usually list (e.g. Raven et al. 2014). In its simplest symbolic notation this reads: $\mathrm{L}=\sum \mathrm{C}$. Because "Life" is an activity at moment $t$ of a given sender-receiver compartment of which there exist many different forms, one can specify it further as:

$$
L(S, t)=\underset{1}{j} C(S, t)
$$

where $\mathbf{L}=$ Life; $\mathbf{S}=$ type of compartment; $\mathbf{t}=$ moment at which the communication acts are executed; $\mathbf{1}=$ lowest level of compartmental organization $(1=$ prokaryotic cell or cell organelle in a eukaryotic cell); $\mathbf{j}=$ highest level of compartmental organization [cell, tissue, organ, organism... aggregate... population, community, the Gaia-level (Lovelock 1995)]. For a symbolic notation that highlights how to compare 'biological' and 'mechanical' life (e.g. computer-life, see De Loof 2015b).

Communication implies handling of information. My definition of information reads: A message contains 'information' when, upon decoding by a competent receiver $(=$ a receiver with the proper receptor $(\mathrm{s})$ ), part of the stored energy in that receiver is mobilized for doing some sort of 'work'. This is the meaning of "AT WORK" in Figure 1A1. If one finds that the definition also requires that time has to be defined as well, I tried to do so: "In my opinion time is invariably a property of a given energy converting system. It is a measure for the inertia of the conversion of a given form of energy (heat, light, chemical etc) into another form(s) plus increase in entropy of the system (second law of thermodynamics). There are as many different times as there are energy converting systems (De Loof 2002).

\section{The smallest and the largest communicating compartments}

The prokaryotic cell is the smallest sender-receiver compartment. The eukaryotic cell is already a higher order unit that came into existence by the principles of symbiogenesis or endosymbiosis (Figure 1B1-2) (Margulis 1981, Margulis and Sagan 2002). The highest level, the whole biosphere on earth (Gaia-level) is the highest one. In between the lowest and highest levels, at least 14 additional levels, each with some specific signalling pathways and/or languages, can be discerned. The $\geq 16$ levels can be grouped into three categories.

a. Compartments restricted to a single individual (levels 1-8): prokaryote, eukaryote, cell aggregate, syncytium, mono-epithelium, polyepithelium, segmented organism, tool utilizing compartment. 
b. Compartments with individuals of the same species (levels 9-14): colony, heterosexual and social compartments, baby inside mother (internal budding) compartment, population/species, electrosphere compartment (e.g. humans linked by telephone, radio etc.).

c. Compartments with individuals belonging to different species (levels 15-16): the community (with nutritional and/or protective aspects), and the planetary or Gaia compartment.

All compartments have been described at length before (De Loof and Vanden Broeck 1996, De Loof 2002). Witzany (2010) handles a similar system. This will not be repeated here.

\section{The Evolution of 'Life': symbolic notation for the evolution of Life and wording of its essence}

Communication is the difference making activity of living- versus non living matter. If $\mathrm{L}=\sum \mathrm{C}$ is an acceptable simple symbolic notation for ' $\mathrm{Life}$ ', the simplest symbolic notation for its evolution becomes:

$$
\Delta \mathrm{L}\left(\mathrm{T}_{2}-\mathrm{T}_{1}\right)=\Delta \sum \mathrm{C}\left(\mathrm{T}_{2}-\mathrm{T}_{1}\right)
$$

$\Delta=$ the change in $\ldots$ (Life, communication activity); $\mathrm{T}_{1}$ and $\mathrm{T}_{2 \text { : }}$ different time points

Evolution concerns the incessantly changing complexes of signalling pathways, chemical and other, that occasionally yield both new species and additional compartmental levels of communicational activity.

This raises questions about the possible mechanisms, genetic- and nongenetic ones instrumental to make communicating compartments and their activities change.

\section{Causes of evolutionary change}

7.1. The (gross) mechanisms causal to the formation of the cited $\geq 16$ levels. These mechanisms are few and relatively simple:

a. Internalization of a smaller compartment(s) into an already existing compartment of the same nature, e.g. the formation of the eukaryotic cell by symbiogenesis (Margulis 1981).

b. Gluing together compartments by a variety of means, e.g. the formation of epithelia.

c. Utilization of tools, e.g. in humans. 
d. Sexuality and development (horizontal gene transfer, asexual, sexual).

e. Nutritive and protective deficiencies elicit bypass strategies

\subsection{Mechanisms operating at the cellular and subcellular level}

7.2.1. Genetic changes. This source of variability in combination with effects of meiotic recombination, hybridisation, genetic drift, migration, assortative mating and selection has been the main focus of neo-Darwinism (Kauffmann 1993, Gould 2002). In particular the various types of mutations (Figure 2) which yield new alleles are very well documented. In recent decades it has become clear that not only genes can be duplicated, but whole genomes as well. In addition, horizontal gene transfer (e.g. natural transfer in bacteria and artificial transfer in fish) has become well documented (Boekels Hogarten et al. 2009; Smith and Spadafora 2005). A possible role for viroids (viral symbiosis: Ryan, 2009) has also been described, in particular from the RNA world into the DNA world (Domingo et al. 2008, Witzany 2012, Mölling 2015).

7.2.2. Epigenetic changes. In particular in the recent two decades, it has been shown that (some) genes can be modified epigenetically under the influence of the environment. The best documented mechanisms are DNA methylation and histone modification by specific enzymes (Figure 2). Temporary changes in control of gene expression can be realized this way (Boekels et al. 2009, Francis 2011, Carey 2012, Shapiro 2011, Noble 2015, Allis et al. 2015). There are also enzymes to reverse the cited modifications. That can take more than one generation, depending on the system and conditions. Epigenetic gene modification is considered by some researchers as a form of Lamarckian type evolution, namely of acquired genetic changes during lifetime. The fact that the changes are, in principle, reversible makes that their role in long-term evolutionary change is not easy to establish.

The clearest example of the power of Lamarckism is Homo. Through teaching, learning and mimicry the species Homo sapiens L. evolves culturally exceptionally fast without any mutations being involved. The digital revolution of the past decades is a good example. In fact cultural evolution is evolution the software way, through the possibilities of the cognitive memory system. In cultural evolution pupils are the functional equivalent of physical children for transmitting information to the next generations. 


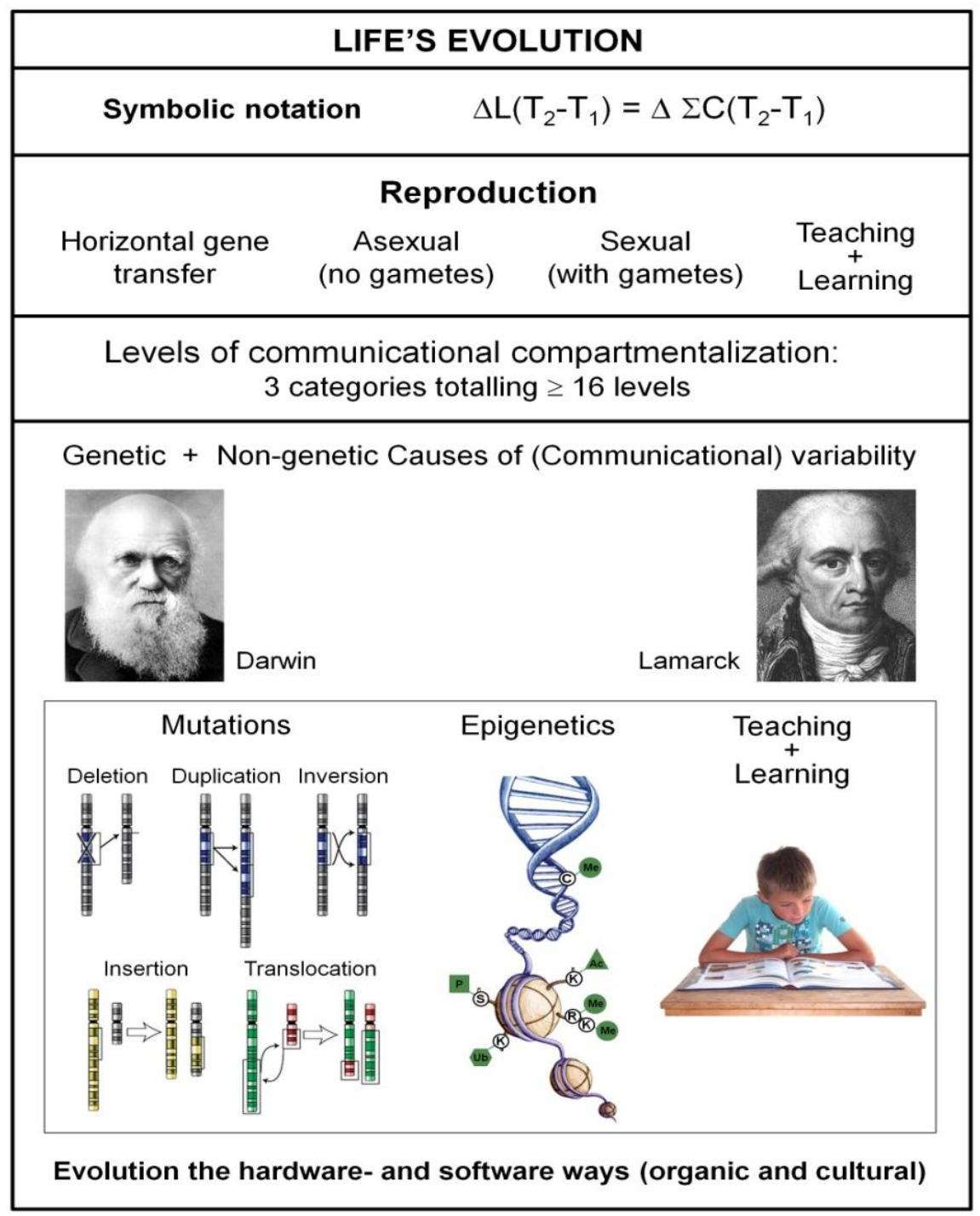

Figure 2. Schematic representation of key facts of the evolution of Life in the course of geological time. Cells have 2 memory systems, a genetic and a cognitive one (Figure 1 B2). Hence where relevant, two types of progeny are possible: physical children and pupils. Mutations are very well documented as sources of genetic variability. In recent decades, it has been uncovered that epigenetic changes may be an important means for adapting - during life time - organisms to a changing environment; epigenetics and cultural evolution urge for upgrading Lamarckism. 
7.2.3. Non-genetic changes, including languages. Although at first sight it may look self-evident that formation of a new species requires a causal mutation in some gene (sets), this is not necessarily the case. Indeed, Grant and Grant (2009) have described how a novel species of Darwin finch came into existence in only a few generations merely by the introduction of a variant in the song, thus by introducing a dialect. That trait was continued through learning and resulted in reproductive isolation.

Biochemists use the term 'signalling pathway' for intracellular (= in an aquatic environment) communication. In the humanities, 'language' (Westling 2014) is a common term for denoting signalling between members of the same species or of other species. The best analyzed language is the one spoken by humans. It is executed in a terrestrial (aerial) environment. It evidently involves other mechanisms than intracellular communication which happens in an aquatic environment. It has multiple variants. Many organisms also use visual and olfactory means of communication. In combination this means that the number of variables in 'languages of all sorts' exceeds by far the number of genes of all different species combined. It also means that there can hardly be two organisms with exactly an identical communication 'bouquet' (Barritt 1994, Witzany 2010): "every single bird (organism) sings its personalized song".

\section{The status of the 'cell concept' needs rethinking}

8.1. 'The cell' is, in origin, a morphological concept. It was Robert Hooke (1635-1703), upon observing the small chambers (= cellulae) in cork who introduced the term 'cellula'. In origin it had no functional meaning. Later it became clear that this cellular structure also occurs in animals, plants, fungi etc. 'The cell' evolved into the universal unit of structure and function. In my opinion, the status of 'the cell' should be reduced to that of the smallest communicating compartment rather than that of the universal unit of structure and function (the universal cell theory of Schleiden and Schwann). Indeed which unit functions as a unit of structure and function depends upon the level of compartmental organization of which there exist at least 16 different types. For example, for all prokaryotes (level 1 of compartmental organization, the prokaryotic cell is indeed the unit. For single celled eukaryotes it is the eukaryotic cell. At the level of the population, it is not the cell anymore but the individual organism (Walsh 2015). Yet the different units of structure and function that are typical for any of the levels of compartmental/communicational organization all reside under the common umbrella of 'sender-receiver unit', the true unit of structure and function of all levels.

8.2. The cell as a miniature electrophoresis chamber. During the past century the subcellular morphology of cells became better and better documented thanks to studies involving novel microscopic techniques. One feature that is not visible with such techniques but that can be visualized with electrophysiological methods has remained undervalued, namely that cells have 
'an electrical dimension' and that most cells and even organisms, if not all, do drive a self-generated electric current through themselves, at least during part of their developmental cycle (Figure 3). The invention of the vibrating probe technique by Lionel Jaffe and Richard Nucitelli (1974) has greatly contributed to the visualization of such currents and to thinking about their roles, in particular with respect to $\mathrm{Ca}^{2+}$-homeostasis. Pioneering work by Jaffe and Woodruff (1979), Woodruff and Telfer (1980), Telfer and Woodruff (2002) on ionic currents and unidirectional transport of charged macromolecules in ovarian follicles of a moth species initiated the idea of self-electrophoresis. This idea was broadened into 'The cell as a miniature electrophoresis chamber' concept (De Loof 1986). For those who are not familiar with the term 'electrophoresis': electrophoresis is since decades a widely used technique in biochemical research for separating charged macromolecules, in particular proteins and nucleic acids.

The major reasons why relatively little emphasis has been given to this property/activity except in a subdomain of developmental biology and in electrophysiological studies (neurobiology, muscle physiology, osmoregulation, etc) is that in many biochemical experiments, the researchers homogenize their experimental cells or tissues first. This procedure destroys the plasma membrane and kills the electrical dimension. It also destroys ionic gradients, in particular the $\mathrm{Ca}^{2+}$-gradients in intracellular membrane-limited compartments [Rough- and Smooth endoplasmic reticulum (RER, SER)]. Furthermore, electrophysiological techniques are less accessible for experimentation than the ones of molecular biology for which numerous ready to use kits are available.

Self-generated electricity is not carried by electrons like in the current from the socket, but by inorganic ions, in particular $\mathrm{H}^{+}, \mathrm{Na}^{+}, \mathrm{K}^{+}, \mathrm{Ca}^{2+}, \mathrm{Mg}^{2+}, \mathrm{Cl}^{-}$, $\mathrm{HCO}_{3}{ }^{-}$. It is evident that such currents and their effects are only partially controlled by gene activity. Hence, as long as the New Synthesis does not incorporate (along with other non-genetic causes of variability) a principle that accounts for 'biological electricity and its roles', it will remain an incomplete theory.

There are two major aspects of cellular electricity. First, such ions are essential for realizing an ionic/voltage gradient over the plasma membrane of all prokaryotic and eukaryotic cells. The average voltage gradient over the plasma membrane (which is about 80 nanometres thick) of an animal cell amounts to about $40 \mathrm{mV}$ which corresponds to a figure of not less than 50,000 Volt per centimetre. Maintaining such huge gradients (homeostasis) is vital to cells, and it requires lots of energy. Second, cells are non-spherical symmetric with respect to their plasma membrane properties. This enables cells to drive a flux of ions, electrogenic or not, through themselves. This is linked to several cellular functions: (coarse) control of gene expression, development, cellular migration, regeneration, multifunctional $\mathrm{Ca}^{2+}$ currents etc. (Jaffe and Nuccitelli 1977, Jaffe 1981, De Loof 1986, Funk 2015). Electrophoresis is a widely used technique in 
biochemical research for separating charged macromolecules, in particular proteins and nucleic acids.

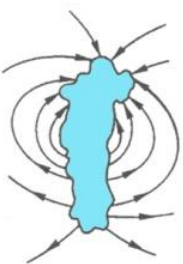

Chaos chaos Ameba

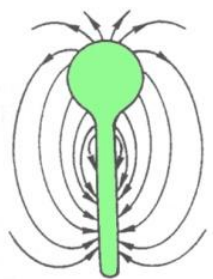

Lilium (lily)

Pollen tube

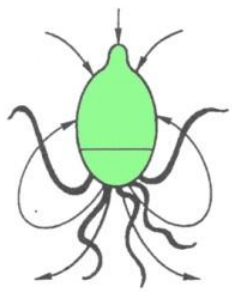

Blastocladiella Water mold

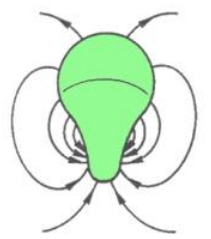

Pelvetia Brown alga

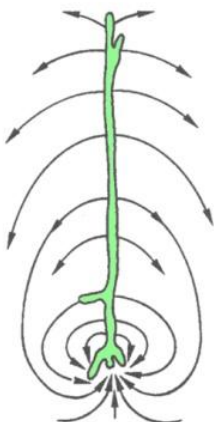

Acetabularia Unicellular green alga

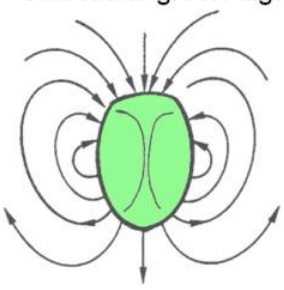

Nicotiana tobaccum Embryo

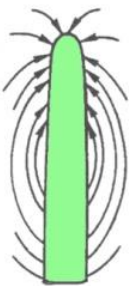

Achlya (hyphe) Water mold

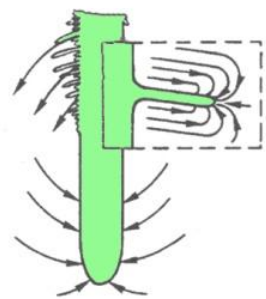

Hordeum (barley) Root tip

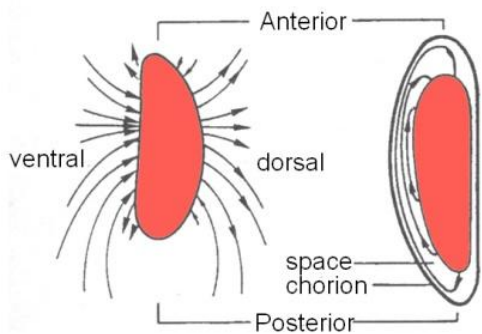

Blatella (cockroach) Oocyte

\section{Xenopus (clawed toad) Oocyte \\ Drosophila (fruit fly) Preblastoderm}

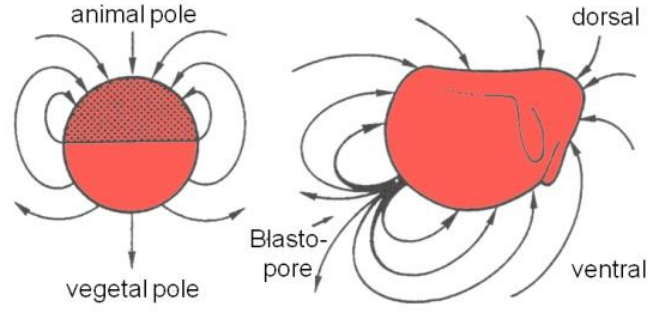

Xenopus

Embryo-Neurula stage

Figure 3. Schematic representation of the electric field around a variety of systems, as measured by the vibrating probe technique developed by Lionel Jaffe and Richard Nuccitelli (1974). The electrogenic ion fluxes are produced by the systems themselves. Adapted from De Loof (1986 and 2002). 
8.3. Lipid membranes are causal to inorganic ionic compartmentalization and act as insulators for ionic cellular electricity. Containing ionic electricity within cellular compartments requires a functional insulator system (Figure 1B4). Unlike electrons, inorganic ions cannot simply pass such membranes by diffusion. This means that lipid membranes are good 'electrical insulators' for 'ionic electricity'. Special ion transporting proteins, namely ion pumps and channels enable transmembrane ion transport. The different types of lipids present in membranes are not coded for by genes like proteins are. Evidently, the enzymes needed for their synthesis are proteins. Membranes accommodate many different types of proteins that have hydrophobic domains. For example, many (G-Protein coupled) transmembrane receptors have 7 hydrophobic domains. The main function of the intracellular membrane systems of eukaryotes is to realize "ionic microenvironments" inside cells in which the activity of some enzymes that are present in membranes (e.g. $\mathrm{Ca}^{2+}$-ATPases in the endoplasmic reticulum) can be controlled. Some factors, physical or chemical that change the fluidity of membranes, can control cellular activities.

8.4. Cells have to be polarized for enabling transcellular ionic currents. For enabling transcellular transport of ions, the ion pumps and channels cannot just freely float in the plane of the membrane. They have to be held in place, e.g. by elements of the cytoskeleton in such a way that they reside in different regions of the membrane. Thus the cell has to be polarized, meaning that the many elements have to be longitudinally oriented (Figure 1B6). This is well documented in both single cells (Figure 1B6) and in epithelia (basal-apical- and lateral localisations of ion transporters). Generating non-spherical asymmetry and polarity is a key issue from early embryonic development on. It is causal to realizing the holistic principle governing development as will be explained next.

8.5. The double asymmetry principle, Evo-Devo, and Ernst Haeckel. Evolutionary developmental biology (evo-devo) compares the developmental processes of different organisms to determine the ancestral relationship between them, and to discover how developmental processes of different organisms evolved (Wikipedia - evo-devo). Since Haeckel's Law (1866) “Ontogeny recapitulates phylogeny", a lot of information has been gained on the comparative molecular genetics and the control mechanisms (e.g. the homeotic genes) of development. A major remaining question is how differential gene expression during development is controlled. Hitherto, the main focus has been on the fine tuning of gene expression by e.g. (macromolecular) transcription factors, while the discovery of the universality of transcellular electric currents carried by inorganic ions, in particular in developing systems (Figure 3) urges for also taking the membrane properties and non-spherical symmetry of cells into consideration. I think the latter deserve a lead role. This becomes apparent from the analysis of how cells become asymmetrical with respect to their membrane-cytoskeletal properties while they keep their genome constant. 
In the rare cases that spherical symmetry occurs at all in eggs, it is only before fertilization. When a sperm enters the egg it makes a small short lasting hole in the plasma membrane. This suffices for allowing some $\mathrm{Ca}^{2+}$ and other ions of which the extracellular concentration is higher than the intracellular one entering the egg. In some species it is well documented that this local increase in $\left[\mathrm{Ca}^{2+}\right]$ initiates a $\mathrm{Ca}^{2+}$-induced $\mathrm{Ca}^{2+}$-release from internal stores. This causes a rearrangement of the cytoskeleton in the cortical layer of the egg. This is best visible in pigmented eggs (e.g. of Amphibia and Ascidia) because the colour pattern of the egg changes. This is the first element of generating non-spherical symmetry in embryonic development (Figure 4). Next the (mitotic) cleavages start. The first cleavage may yield bilaterally symmetrical left-right blastomeres. Not later than the third cleavage, blastomeres are formed which all differ from each other in their plasma membrane-cytoskeletal properties but which have an identical genome because the cell division involved is mitosis, not meiosis. This principle is illustrated in Figure 4 in which five variables are depicted; ion pumps and channels, the form of the cytoskeleton, maternal messenger RNAs and protein gradients. Other known variables are not depicted. This figure is meant to illustrate the importance of the "double asymmetry principle" in early development and its consequences for later development and functioning.

In my opinion, the holistic principle that governs development reads (Figure 1B3): "Keep the genome constant during the successive mitotic divisions (some exceptions as the random inactivation of the second $\mathrm{X}$-chromosome in mammals not taken into account) and generate cells that all differ in their plasma membrane-cytoskeletal properties. Because of the latter, they can direct differential gene expression-protein synthesis in two ways: first by creating specific inorganic ion environments around the genes (= coarse regulation of gene expression, see section 8.7), and second, later in development when transcription starts by the fine tuning mechanism of gene expression in which macromolecular transcription factors are the main actors (De Loof et al. 1992, 1993b).

One should also keep in mind that actin, the most prominent and universal of all cytoskeletal proteins in eukaryotic cells has very special electrical properties which makes it a candidate player in conduction electricity to specific sites in the cell (Lin and Cantiello 1993, De Loof 2002). Finally, the nonspherical symmetry is a typical feature of any sender-receiver compartment. 


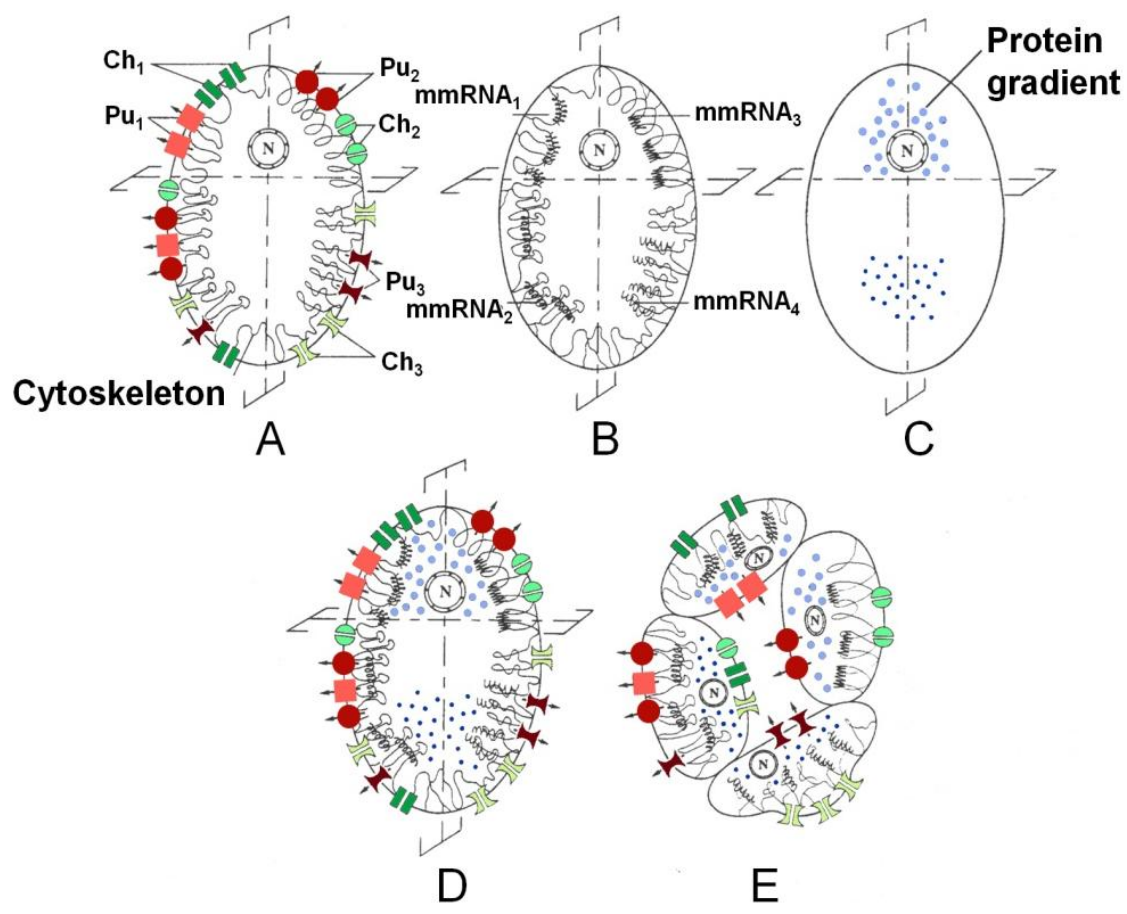

Figure 4. Schematic representation of 'the double asymmetry principle' that is instrumental to the essence of development, namely: "Keep during the successive mitotic divisions the genome constant, but change over and over again its inorganic ion and/or macromolecular development". Mechanisms instrumental in the functional asymmetry in the stem cell (zygote) of a hypothetical 4-celled, epithelially organized organism (animal) (A-E) (modified after De Loof, 1993b). First, an asymmetrical distribution is realized (i) of the plasma membrane-cytoskeletal complex $\left(\mathrm{A}: \mathrm{Pu}_{1}-\mathrm{Pu}_{3}=3\right.$ types of ion pumps; $\mathrm{Ch}_{1}$ $\mathrm{Ch}_{3}=3$ types of ion channels); (ii) and/or of maternal messenger RNAs (B: mmRNA ${ }^{-}$ $\mathrm{mmRNA}_{4}$, some of which can be anchored to the cytoskeleton; (iii) and/or of gradients of certain proteins in the cytoplasm/yolk (C) (e.g. of the bicoid and nanos gradients in eggs of Drosophila). Next the egg is cleaved in an asymmetrical way. Sometimes this happens already during the first cleavage, but never later than during the third. In D, which represents the superposition of $\mathrm{A}, \mathrm{B}$, and $\mathrm{C}$, it is the second cleavage which will give rise to four different cell types, all sharing the same identical genome (E).

\subsection{Control of intracellular inorganic ion homeostasis is complex.} Numerous factors and mechanisms influence the cytoplasmic ionic environment a. Inorganic ion types present in the cytoplasm and in the intracellular membrane compartments. Free ions. Ions bound to macromolecules. Ionic gradients. Cytoplasmic electric fields and electroosmosis (Andreev 2013). 
b. Types of ion pumps and ion channels, exchangers etc. in the different membranes.

c. Their localization in the plasma membrane and in internal membranes.

d. The way they are distributed over the membrane, either symmetrically in unifacial cells (which may be very rare or even nonexistent) or asymmetrically in bifacial or multifacial cells (= probably the 'normal' type).

e. All sorts of gating mechanisms for channels.

f. Transcellular currents can be electroneutral or electrogenic.

g. The localization of $\mathrm{Ca}^{2+}$ stores and the ways to set $\mathrm{Ca}^{2+}$ free and to achieve its reuptake in the stores.

h. Intracellular $\mathrm{Ca}^{2+}$-currents and 'explosions' (Jaffe 1991, 1993).

i. The role of the lipid composition of the cell membranes, e.g. with respect to the fluidity of membranes.

j. The role of receptors.

k. Ionic compartmentalization of the nucleus (references in De Loof et al. 2014). The localization of the nucleus in the cell (e.g. adjacent to the plasma membrane like in the skeletal muscle cells, or away from it, like in heart muscle cells).

1. The role of the RER and of the Golgi (De Loof, 2015a) as the means to remove surplus $\mathrm{Ca}^{2+}$ from the cytoplasm, bound to secreted proteins. The role of the SER (and associated small vesicles), of mitochondrial $\mathrm{Ca}^{2+}$ stores, and of $\mathrm{Ca}^{2+}$-binding proteins (e.g. calmodulin, calbindin) in $\mathrm{Ca}^{2+}$-homeostasis has also to be taken into account.

$\mathrm{m}$. The nature of electrical contacts (coupling) between neighbouring cells.

n. Lateral electrophoresis in the plane of the plasma membrane.

o. Differences in local resistivity in the cytoplasm.

In short, the internal ionic environment in the cell's interior depends on so many factors and control systems that probably each cell on earth has the ability 
to create a "personalized cytoplasmic ionic environment". This suggests a causal relationship with some cellular functions.

8.7. The effect of inorganic ions on gene expression: a system for coarse regulation. Of particular interest in the context of this paper is the relationship between inorganic ions and gene expression. The question is: does the intracellular ionic environment contribute to determining which genes should be transcribed and how this is achieved?

The pioneering experiments of M. Lezzi and H. Kroeger and others in the 1960-70ties on the role of inorganic ions on changing puffing patters at specific locations in the polytene chromosomes of certain (model) fly (Diptera) model species (Drosophila, Chironomus) yielded challenging results (summary and references in De Loof et al. 2014). Briefly, the cited authors demonstrated that specific puffing patterns which were thought be induced by specific (insect) hormones such as ecdysone (a steroid) and juvenile hormone (a sesquiterpenoid) could as well be induced by incubating the salivary glands in media with a specific inorganic ionic composition in the absence of any hormone. This indicated that inorganic ions may represent an important level of coarse regulation of gene expression. The target is the chromatin structure. Apparently some chromatin regions react differentially, by condensation or decondensation to changes in specific ionic environments. This is thought to make such regions more or less accessible to the fine tuning mechanisms of transcription. In particular the concentrations of $\mathrm{H}^{+}$and $\mathrm{Ca}^{2+}$ are known to influence the spatial conformation of many proteins and hence their activity as well. The experiments of Lezzi and Kroeger have undeservedly turned into oblivion in recent decades. The reason is that fine tuning of gene expression by transcription factors attracted more interest and funding.

\section{9. $\mathrm{Ca}^{2+}$-homeostasis: cells live in an ocean of a very toxic ion, namely $\mathrm{Ca}^{2+}$}

The duality in functions of $\mathrm{Ca}^{2+}$, namely very toxic but nevertheless beneficial under certain conditions is intriguing (Torday and Rehan 2012; Torday 2013, 2014). Indeed, $\mathrm{Ca}^{2+}$ is well known as a secondary messenger in signal transduction pathways. This role is intuitively considered to be beneficial. Yet, if one analyzes the system, this role is due to the fact that at 'higher' concentrations $\mathrm{Ca}^{2+}$ is toxic because it can change the conformation of some types of macromolecules, in particular proteins. This is clearly illustrated by the effect of rising $\mathrm{Ca}^{2+}$ concentrations on the cytoskeletal proteins in muscle cells. It results in contraction. $\mathrm{Ca}^{2+}$ is thus causal to behaviour that in its turn is instrumental to evolution (Jablonka and Lamb 2014). In resting conditions, thus in unstimulated cells, the free cytoplasmic $\mathrm{Ca}^{2+}$ concentration amounts to about 100 nanomolar which is very low. The extracellular $\left[\mathrm{Ca}^{2+}\right]$ is many orders of magnitude higher, about 1-60 millimolar (2 mM in blood) (Figure 1B5). This represents a huge gradient of a very toxic substance. One could say that cells bath in a life-threatening watery solution. They can only survive if they can keep 
the concentration of cytoplasmic free $\mathrm{Ca}^{2+}$ very low. But the plasma membrane is not perfectly impermeable to $\mathrm{Ca}^{2+}$. This means that there is a continuous influx of $\mathrm{Ca}^{2+}$. In some cells this influx is very low, in others it is higher e.g. under the influence of some hormones. Thus cells must continuously invest energy in pumping $\mathrm{Ca}^{2+}$ out of the cell or/and in storing some excess $\mathrm{Ca}^{2+}$ in intracellular stores, e.g. in the lumen of the endoplasmic reticulum and the mitochondria. In case much more $\mathrm{Ca}^{2+}$ enters the cell than the plasma membrane $\mathrm{Ca}^{2+}$-ATPases (PMCAs) can extrude, an additional system is activated. Indeed, in that case the RER is activated to start synthesizing $\mathrm{Ca}^{2+}$-binding proteins that are packed into vesicles in the Golgi system and next are secreted into the extracellular space. Thus the role of RER is not simply to secrete proteins, but to secrete $\mathrm{Ca}^{2+}$-binding proteins. From an evolutionary point of view, female mammals do not produce milk to feed their young, but to remove excess toxic $\mathrm{Ca}^{2+}$ that under the influence of hormones enters the mammary gland cells. Similarly, the calcareous egg shell of birds was not 'invented' for the protection of the egg content and growing embryo, but as a death-escaping mechanism for removing excess $\mathrm{Ca}^{2+}$ from the female genital tract. This has been described in the 'Calcigender-paradigm (De Loof 2014). $\mathrm{Ca}^{2+}$-homeostasis is a very ancient system and signalling pathway that is omnipresent in all cells. Therefore, it deserves a prominent place in teaching the cell biological basis of evolution.

\section{Adaptation and the universal driving force of evolution}

10.1. External harsh conditions. In the classical neo-Darwinian approach of evolution, the best documented cause of selection is selection by harsh external conditions: too hot, too cold, too salty, too dry, too many predators or parasites etc. This could be grouped under the common denominator: 'too high external gradients' which individuals can or cannot cope with. There are gradations among the capacity of organisms towards problem-solving. To illustrate that one should not exclusively 'blame' external conditions in the process of selection; it may help to analyze the course of events when doing an exam. The general perception is that the examiner, not the pupils who take the exam does the selection. Yet, if one analyses the system, the opposite conclusion emerges. The teacher-examiner formulates the questions. In evolutionary wording, he/she constructs some gradient, like nature would build temperature-, light-, etc.- gradients. It is up to the students to show their abilities to overcome the exam-gradient. Thus, they engage in self-selection. The examiner only lists their success or failure. The principle of self-selection is further strengthened when the student succeeds in solving the problem by feedback, i.e. by answering in such a way that the sender/teacher will (deliberately or not) lower the gradient (e.g. by changing the subject of examination).

\subsection{The Gradient-Provoked Swelling/Shrinking Self-Selection} Principle, the GP-Triple S Principle. In addition to the external gradients, there is an additional cause of selection that is most of the time overlooked, 
namely too high (ionic) gradients at the (sub)cellular level, thus internal gradients. As soon as a new communicating compartment comes into existence, it is immediately subjected to the effects of its own gradients.

A typical example is the toxic effect of sustained elevated $\mathrm{Ca}^{2+}$ concentration (or $\mathrm{H}^{+}$-concentration). When a spermatozoon of a sea urchin (a well studied model) penetrates the egg, a small hole is made in the plasma membrane. Because the free $\left[\mathrm{Ca}^{2+}\right]$ is higher outside than inside the cell, some $\mathrm{Ca}^{2+}$ will locally enter the cell. This rise can cause a sudden release of $\mathrm{Ca}^{2+}$ from intracellular $\mathrm{Ca}^{2+}$-storage sites. This is known as $\mathrm{Ca}^{2+}$-induced $\mathrm{Ca}^{2+}$ release, or as a $\mathrm{Ca}^{2+}$-explosion. Such explosions happen all the time in contracting muscle cells. If this $\mathrm{Ca}^{2+}$-rise lasts too long, the cell can get damaged and may die. This principle also applies to other ions, e.g. $\mathrm{K}^{+}$and $\mathrm{Na}^{+}$at the moment that during cell division the newly forming membranes are still not fully impermeable to these inorganic ions. If substantial changes in inorganic ion concentrations occur, osmotic effects may result in swelling or shrinking, depending on the conditions. After the newly formed entity has proven that it can cope with its own internal ionic gradients, it will next be subjected to the gradients of the environment. This is the essence of the Gradient-Provoked Swelling/Shrinking and Self-Selection principle (De Loof, 2002). Directly at the birth of any new compartment (cell division, population formation) the nascent system tests if it can cope with its own (internal) gradients. If it cannot, death of the entity ensues. One could say that nature handles "the short pain rule".

10.3. Any act of communication is a problem-solving act. The essence of adaptation is that individuals, by themselves or by cooperating with others (Ridley 2000, Bauer 2010) can solve particular problems. Karl Popper already pointed out decades ago that evolution is not just a passive process (Niemann 2014). He argued that the creative forces which are at work in evolution are "knowledge and creativity" but he had no idea how they came into existence or on what principle they are based. The idea that intelligence is omnipresent in nature, including in plants, has gained support over the years. It yielded the ideas of evolution as a creative process" (Bauer 2010), of purposive organismal agency (Vane-Wright 2014), of the cooperative gene (Ridley 2000) contrasting Richard Dawkin's (1976) "The Selfish Gene" concept, and several others. It is evidently advantageous if organisms can anticipate problems which represent an aspect of intelligence (Vertosick 2002, Pookottil 2013).

The nature of this force(s) and the source of this universal enigmatic intelligence become apparent if one analyses the principles of communication. Indeed, intelligence requires handling of- and responding to incoming information. That is exactly what living systems, whatever their architecture is, incessantly do (Bray 2009, Lamm and Unger 2011, Trewanas 2014). This made me advance the view that - at the cellular level - in fact any act of a communication is a problem-solving act. Indeed, any message that reaches the boundary of a competent receiver (= with the right type of receptors) has to be 
captured, decoded, amplified and responded to sooner or later. Most problems faced by organisms are solved in an automated way because decoding programs have been installed in the cognitive memory system in advance (De Loof 2002).

Thus, the ability to problem-solving, among others (e.g. the ability to adapt or the ability to cope with the adversely changed external condition) a generally accepted criterion of intelligence, does neither automatically follow from genes nor from the central dogma. It follows from the organization of living matter as sender-receiver systems. It follows that all life is intelligent by definition (Vertosick 2002; De Loof 2002). Some may argue that genuine intelligence requires the presence of consciousness and free will. I have argued before that free will emerges when more than one possibility for solving a particular problem becomes available, necessitating making a choice. I suggested the name "bifurcation point" for this possibility (Figure 1A2) (De Loof 2002). There are gradations in free will; the larger the number of choices that have to be made at any given moment, the higher 'the level of free will'. According to Trewanas and Baluska (2011) consciousness is ubiquitous, be it that unambiguously defining consciousness is not self-evident.

10.4 There is no goal whatsoever in evolution, it is a blind process, hence, "to be prepared for the future" is a successful strategy.

Indeed, it cannot be predicted when and how the environmental and intraorganismal conditions will change in the future, in particular in the distant future. A problem can only be solved if the program(s) for decoding, amplifying and responding to an incoming message are preinstalled. Yet, organisms are usually unable to anticipate which problems they will face. Thus they develop and evolve blindly. How do they nevertheless "foresee" the future? The best strategy for optimizing survival in the long run is preparing for the unforeseen. One possible strategy is establishing multivalent signalling pathways that, if necessary, can be switched from serving in one condition to serving in another. An example is the use of prolactin, an evolutionary ancient neurohormone in vertebrates. In fish, which were long ago distant ancestors of mammals, its functional role was and still is in ormoregulation which is very important in their aquatic environment. In mammals, which exchanged the aquatic environment for a terrestrial one, it serves, among other functions in milk production. Another strategy, also endocrine in nature, is very well developed in insects. Many of their approximately 50-100 genes coding for neuropeptides contain multiple copies of the peptide-coding region, usually all slightly different from each other. In case a mutation occurs in their receptor, there is a chance that one of the 'unused' peptide isoforms can repair the defect. A third strategy, again in insects, is to multiply a given gene. An appealing example is insect insulin. In mammals there is one insulin gene per haploid genome. In the silkworm Bombyx mori, bombyxin which is a member of the insulin superfamily is coded by over 40 different genes (Kondo et al. 1996, Aslam et al. 2011). Still another possible strategy is the use of 'promiscuous' receptors, thus of receptors to which more 
than one than one ligand can bind. In such system, not only the affinity of the ligand for the receptor but also the relative concentrations of the various ligands play a role. This enables functional plasticity without the need of a mutation. The $\mathrm{Ca}^{2+}$-ATPases present in the membranes of the endoplasmic reticulum may have such receptor properties (De Loof, 2015a).

In cultural evolution of our own species, our education system tries to prepare the pupils for coping with future challenges by teaching general methods (reading, writing, mathematics, technology etc), additional languages to the mother tongue, improved verbal expression etc. This "be prepared strategy" enables organisms to partially direct their own evolution.

10.5. Survival of the fitter: the better problem-solvers. The best problem-solvers have better chances for survival and for reproduction. Not only competition, aggression and struggle, but cooperation, symbiosis and synergism can also be instrumental to problem-solving and to increased fitness.

10.6. Cultural evolution. How organic- and cultural evolution can be seamlessly integrated has been outlined by De Loof (2014). Cultural evolution is evolution "the software way". Some problems are solved the hardware way using the principles of the genetic memory; others are solved through the principles of the cognitive memory.

10.7. The driving force of Life's evolution is Life itself: Natural gradients are only the 'provokers'. Darwin (1859) defined Natural Selection as follows: "This preservation of favourable variation and rejection of injurious variation, I call Natural Selection". This wording is so general that it comforts both mechanisms instrumental to genetic- and non-genetic variation. The reason why nevertheless Natural Selection has long been a matter of debate (see introduction) is that it is not clear whether Natural Selection is the universal cause, thus the driving force of evolution rather than being itself the result of a preceding 'something' that then is the true driving force. In my opinion, in Darwin's wording Natural Selection stands for being the result of 'something'. In the communication approach of Life and its evolution, that 'something' is nothing else than problem-solving activity that precedes selection. But problemsolving activity is intrinsically connected, at the (sub)cellular level (De Loof $2015 b$ ) with communication activity that itself is a synonym for Life (as an activity).

All of this results in a most remarkable conclusion, namely that Life itself is the universal driving force of its own evolution. Everyone including myself when I first deduced this conclusion will intuitively reject this conclusion because of being a circular conclusion, thus worthless. However, it is not a circular reasoning/deduction, but a spiral-like one. This follows from the fact that feedback mechanisms in communication, thus in Life as an activity, are never circular but spiral-like (Figure 1A2).

Because of its intrinsic 'communication-nature' Life cannot be anything other than a continuous change in the short- (development) and long (evolution) 
run, and this almost always unidirectionally (some mutations are reversible). Through problem-solving it also harbours the capacity to partially direct its own evolution. I already stated elsewhere (De Loof 2015b) that one should admire the beauty of this principle.

\section{Proof of principle: impossible or already documented?}

The time has come to abandon the view that the generation of new species is the central issue in evolution. As stated before, the evolution of Life concerns ever changing complexes of signalling pathways, chemical and other, that occasionally yield new species and additional levels of communicational compartmentalization. Do we have proof that this really happens?

At the level of biochemical signalling pathways, the analysis of such pathways, which operate during the development of various species of vertebrates, invertebrates, and plants, has shown some of the changes that took place in the course of time. For instance, comparative endocrinologists have showed how the hormonal signalling system evolved (De Loof et al. 2012). Human language(s) also changes rapidly, and this contributes to changes through cultural evolution.

The coming into existence of a new species is often thought to take a long time, at least in multicellular eukaryotic species. One cannot do experiments that require time spans measured in the geological time scale. Generating a new species by means of the principles of communication which operate in cultural evolution can be achieved much faster. A well documented example is the coming into existence of a new Darwin finch species on the Galápagos island, Daphne Major, that took only 4-5 generations, starting in 1981. It did not involve multiple mutations, only the immigration of a single Geoszpiza fortis male that sang a slightly different song. The course of events that resulted in a new species in only a few years has been described by Grant and Grant (2009).

A new level of compartmental organization that I named "the electrosphere", in which humans get linked by telephone, radio, television etc., was initiated by the invention of the telephone (patent in 1876) by Alexander Graham Bell. In less than two centuries, it drastically changed the functioning of the species Homo sapiens L. It also initiated the possibility of intergalactic communication, another recently acquired level of communicational compartmentalization.

An observer who would have watched the changes in human behaviour during the past few decades may conclude that like the cited new finch species, a new Homo sapiens species that communicates electronically (fingertips and telephone) instead of by voice without sophisticated mechanical tools has come into existence in a very short time, without mutations. Thus, communication is indeed a major driving force of evolution. It can act very fast and it does not necessarily require mutations. 


\section{Discussion}

Hundreds of thousands of pages have been published on biological evolution and its mechanisms. That makes it very difficult to see the forest (the central principle, namely the nature of Life) for the trees (the various mechanisms instrumental to its change) (Pagel 2002). Yet, the universe we live in is based upon very simple principles, e.g. the proton as the universal building block for all elements of the table of Mendeleyev, the triplet code for the 20 different amino acids etc. The problem is that these principles enable an enormous variability and that only an observer who stands back from the picture, can see from which general principle the variants are manifestations. The variability in morphological and physiological biological systems gives us the impression that it is unlikely that they are based upon a simple common principle. Yet, with some logical thinking, it becomes clear that there is a central principle, namely that all living matter is constructed as sender-receiver communicating compartments that incessantly talk (= handle information), thereby solving problems, most of them in an automated way.

As already also stated by other authors (Witzany 2010, Torday and Rehan 2012, Westling 2013, Jablonka and Lamb 2014, and others) the communicationapproach urges for an adequate follow-up in evolutionary theory. How did the first such sender-receiver come into existence? Was a potential genetic information-carrier (RNA, DNA, proteins?) first, or was a proteinaceous 'clothes hanger' first, e.g. an actin-like molecule to which RNA and enzymes etc could be suspended (De Loof 1993a), or did co-evolution of code and structure occur (Caetano-Anollés 2010)? How did it next give birth, during approximately 3.5 billion years to the multitude of different communicating compartments, ever more complex in structure and with ever novel signalling pathways/languages? From this point of view, evolution is about changing languages and concurrent deciphering programs of signs (semiotics) in cultural (Wheeler 2006, Kull and Emmeche 2011) and organic (De Loof 2002) evolution.

Insight in the successive levels of communicational compartmentalization is an absolute necessity for bringing order in the tangle of theories on evolution. As long as evolutionary biologists do not better specify which level (of the 16 levels in my classification system) they describe the mechanisms causal to evolution, the Babylonian confusion of tongues and the yes-no debate (Laland et al. 2014) will unnecessarily continue. It is evident that describing evolution at the cellular level requires another vocabulary, namely a biochemical one, than the one needed for describing the evolution of a population of e.g. multicellular animals. Here a mathematical quantitative approach may be better suited. But as outlined in the idea of "A Darwinian population" (Godfrey-Smith 2009) genes are not the only source of evolutionary variability. Evolution is not an either-or story, but a complex and-and story of all mechanisms instrumental to generating variability at each of the successive levels of organization of the entity of which 
one intends to describe the evolution. Translating the mathematical (multidimensional) landscape models of the past decades (e.g. Mayr 1993, Kauffmann 1993, and others) into signalling pathway/language landscapes will undoubtedly be a challenge, given the very large number of possible variables in communication.

If unbiased observers ignorant about the principles of development would be asked to describe with histological terminology the structure of a multicellular animal, they would probably conclude that such organisms are symbiotic units of various unicellular species. Because of their different morphology and because they all exert different functions, the observers would probably also conclude that they must have a different genome. We now know that the variability which is generated during development is due to differential use of (part of) the same genome (Gilbert 2013, Wolpert et al 2015). All principles of development should also be taken into account in evolutionary theory, for which they represent the foundation. Yet there is one major difference. Indeed, there is no role for mutations in development of an organism but in the course of geological time the genome, signalling pathways in development etc. are subject to mutations making that novel species can come into existence. Thus evolution $=$ development + mutations + other, non-genetic causes of variability.

Epigenetic changes can be considered as a form of Lamarckian transfer of changes in genetic information that were acquired during life and that can be transferred to one or in some cases even more that one generation. A typical example is the transfer of epigenetic information inherent to crowding during early larval life of locusts. It takes more than one generation to erase this information and to restore the solitarious phase (Falkenhayn et al. 2013, Ernst et al. 2015). Advances in epigenetics have been reviewed by Carey (2012), Boekels Gogarten et al. (2009), Noble (2015) and others. The best example of Lamarckian evolution is cultural evolution, which is, in my opinion evolution 'the software way, thus through the as yet largely unknown principles of cognitive memory. 'Pupils' are the functional equivalent of 'physical children' in transfer of information to the next generations (Figure 2). Lamarck has been criticized for his "during life acquired characteristics are heritable". For some aspects of evolutionary theory, he deserves rehabilitation (Jablonka et al 1998).

As stated in the Introduction, the status of 'Natural Selection' continues to be a thorny issue in contemporary evolutionary theory. Nothing new under the sun: it has been so since Darwin launched his "On the origin of Species by means of Natural Selection" (e.g. Williams 1966). A major point of contention is: Is Selection a force (with an aspect of energy in it), or is it itself the passive result of 'something' that precedes selection? This question cannot be conclusively answered in the genetics-based approach of the New Synthesis. In neo-Darwinism, for lack of alternative, Darwin's Natural Selection which he defined in an open way (see before), became more and more narrowed to a 
merely genetics-based process by some of his followers. Not everybody agreed with this approach. In the communication/problem-solving approach of MegaEvolution (De Loof 2002), an alternative was advanced, namely that selection is the passive outcome of preceding problem-solving activity. I realize that Selection as the universal driving force of evolution has become 'cultural heritage vocabulary', thus untouchable, and that my alternative may elicit disbelief and rejection, at least at first sight. That is the normal fate of any novel change in paradigm.

As Pigliucci (2007) pointed out, once a science is established, conceptual frameworks tend to expand, rather than being replaced by a novel paradigm even when such replacement can be argued for. Formulating a novel paradigm is one thing, making it teachable to undergraduate- and graduate students is at least as important. I hope that the figures in this paper enable students to quickly catch which elements are truly instrumental to the change in paradigm from neoDarwinism to the evolution of Life (Mega-Evolution) and which physiological principles deserve more attention in evolutionary theory. In a single sentence, the essence is: "Nothing in biology and evolutionary theory makes sense except in the light of communication and problem-solving activities" (paraphrased after Theodosius Dobzhansky (De Loof 2014).

\section{Acknowledgements}

My thanks to the thousands of students who by answering my exam questions helped to shape my ideas on how to formulate the principles of evolution. My sincere thanks as well to Marijke Christiaens and son Senne Hoste (Figure 2) and Julie Puttemans for their help with the figures. Eight anonymous colleagues reviewed this paper and offered constructive suggestions.

\section{Literature Cited}

Allis, C. D., M-L. Caparros, T. Jenuwein, and D. Reinberg (Editors). 2015. Epigenetics (Second Edition). Cold Spring Harbor Laboratory Press. Cold Spring Harbor, New York, USA. 984 pp.

Andreev, V. P. 2013. Cytoplasmic electric fields and electroosmosis: possible solution for the paradoxes of intracellular transport of macromolecules. PLoS One 8(4): e61884. http://dx.doi.org/10.1371/journal.pone.0061884

Aslam, A.F., T. Kiya, K. Mita, and M. Iwami. 2011. Identification of novel bombyxin genes from the genome of the silkmoth Bombyx mori and analyses of their expression. Zoological Science 28:609-616. http://dx.doi.org/10.2108/zsj.28.609

Baluška, F. 2011. Evolution in Revolution. A paradigm shift in our understanding of life and biological evolution. Communicative \& Integrative Biology 4:523-525. http://dx.doi.org/10.4161/cib.17702

Baluška, F. and G. Witzany. 2013. At the dawn of a new revolution in life sciences. World Journal of Biological Chemistry 4:13-15. http://dx.doi.org/10.4331/wjbc.v4.i2.13

Barritt, G. J. 1994. Communication within Animal Cells. Oxford University Press. Oxford, England, UK. 360 pp.

Bennett, A. 2014. Evolution Revolution. Evolution is True, Darwin is wrong. Lexem Publishing. Los Angeles, California, USA. 414 pp.

Bauer, J. 2010. Das kooperative Gen: Evolution als kreativer Prozess (The Cooperative Gene: Evolution as a Creative Process). Wilhelm Heyne Verlag. München, Germany. 224 pp. 
Boekels Gogarten, M., J. P. Gogarten, and L. Olendzenski. 2009. Horizontal Gene Transfer. Genomes in Flux. Spinger Protocols. Methods in Molecular Biology. Humana Press. Totowa, New Jersey, USA 552 pp. http://dx.doi.org/10.1007/978-1-60327-853-9

Bray, D. 2009. Wetware. A Computer in Every Living Cell. Yale University Press. New Haven, Connecticut, USA. $280 \mathrm{pp}$.

Caetano-Anollés, G. 2010. Evolutionary Genomics and Systems Biology. John Wiley and Sons, Inc. Hoboken, New Jersey, USA. 466 pp. http://dx.doi.org/10.1002/9780470570418

Carey, N. 2012. The Epigenetics Revolution: How Modern Biology is Rewriting our Understanding of Genetics, Disease, and Inheritance. Columbia University Press. New York, USA. $352 \mathrm{pp}$.

Chen, S., D. Cai, K. Pearce, P.Y-W. Sun, A.C. Roberts, and D. L. Glanzman. 2014. Reinstatement of long-term memory following erasure of its behavioural and synaptic expression in Aplysia. eLife 2014;3:e03896. doi: 10.7554/eLife.03896.

Crick, F. 1970. Central dogma of molecular biology. Nature 227:561-563. http://dx.doi.org/10.1038/227561a0

Danchin, E. and A. Pocheville. 2014. Inheritance is where physiology meets evolution. Journal of Physiology 532 (11):2307-2317. http://dx.doi.org/10.1113/jphysiol.2014.272096

Danchin, E., A. Charmantier, F.A. Champagne, A. Mesoudi, B. Pujol, and S. Blanchet. 2011. Beyond DNA: integrating inclusive inheritance into an extended theory of evolution. Nature Genetics Reviews 12:475-486. http://dx.doi.org/10.1038/nrg3028

Darwin, C. 1859. On the origin of species by means of natural selection, or the preservation of favored races in the struggle for life. Murray, London, England, UK 502 pp.

Dawkins, R. 1976. The Selfish Gene. Oxford University Press. Oxford, England, UK. 352 pp.

De Loof, A. 1986. The electrical dimension of cells: the cell as a miniature electrophoresis chamber. International Review of Cytology 104:251-352. http://dx.doi.org/10.1016/S00747696(08)61927-0

De Loof, A. 1993a. Schrödinger 50 years ago: "What is Life?" "The ability to communicate", a plausible reply? International Journal of Biochemistry 25:1715-1721. http://dx.doi.org/10.1016/0020-711X(88)90298-4

De Loof, A., 1993b. Differentiation: Keep the genome constant but change over and over again its ionic and/or macromolecular environment". A conceptual synthesis. Belgian Journal of Zoology 123:77-91.

De Loof, A. 2002. Communication, Life, Mega-Evolution. Decrypting Life's Nature. Leuven University Press. Leuven, Belgium. 346 pp.

De Loof, A. 2012. Endocrine archeology: do insects retain ancestrally inherited counterparts of the vertebrate releasing hormones GnRH, GHRH, TRH, and CRF? General and Comparative Endocrinology 177:18-27. doi: 10.1016/j.ygce.2012.02.002.

De Loof, A. 2014. Organic and cultural evolution can be seamlessly integrated using the principles of communication and problem-solving: The foundations for an Extended Evolutionary Synthesis (EES) as outlined in the Mega-Evolution concept. Life: The Excitement of Biology 2(4):247-269. doi: 10.978444/LEB2(4)DeLoof.01

De Loof, A. 2015a. The essence of female-male physiological dimorphism: differential Ca2+homeostasis enabled by the interplay between farnesol-like endogenous sesquiterpenopids and sex-steroids? The Calcigender paradigm. General and Comparative Endocrinology 211:131-146. doi: 10.1016/ygcen.2014.12.003

De Loof, A. 2015b. How to deduce and teach the logical and unambiguous answer, namely L = $\Sigma \mathrm{C}$, to "What is Life?" using the principles of communication? Communicative \& Integrative Biology. http://dx.doi.org/10.1080/19420889.2015.105977

De Loof, A., P. Callaerts, and J. Vanden Broeck. 1992. The pivotal role of the plasma membranecytoskeletal complex and epithelium formation in animals. Comparative Biochemistry and Physiology 101A:639-651. http://dx.doi.org/10.1016/0300-9629(92)90338-Q 
De Loof, A., W. De Haes, T. Janssen, and L. Schoofs. 2014. The essence of insect metamorphosis and aging: electrical rewiring of cells driven by the principles of juvenile hormone-dependent Ca2+-homeostasis. General and Comparative Endocrinology 199:70-85. http://dx.doi.org/10.1016/j.ygcen.2014.01.009

De Loof, A. and J. Vanden Broeck. 1996. Communication: the key to defining "life", "death" and the force driving evolution. "Organic chemistry-based-" versus "artificial" life. Belgian Journal of Zoology 125:5-28.

Dobzhansky, T. 1973. Nothing in biology makes sense except in the light of evolution. American Biology Teacher 35:125-129. http://dx.doi.org/10.2307/4444260

Domingo, E., C. R. Parrish, and J. J. Holland. 2008. Origin and Evolution of Viruses (Second Edition). Academic Press, Elsevier, London, England, UK. 560 pp.

Eco, U. 1978. A Theory of Semiotics. Indiana University Press. Bloomington, Indiana, USA. 368 pp.

Ernst, U. R., M. B. Van Hiel, G. Depuydt, B. Boerjan, A. De Loof, and L. Schoofs. 2015. Epigenetics and locust phase transition. Journal of Experimental Biology 218(1):88-99. http://dx.doi.org/10.1242/jeb.107078

Falckenhayn, C., B. Boerjan, G. Raddatz, M. Frohme, L. Schoofs, and F. Lyko. 2013. Characterization of genome methylation patterns in the desert locust Schistocerca gregaria. Journal of Experimental Biology 216 (8):1423-1429. http://dx.doi.org/10.1242/jeb.080754

Fox Keller, E. 2002. The Century of the Gene. Harvard University Press. Cambridge, Massachusetts, USA. 196 pp.

Francis, R.C. 2011. Epigenetics. The Ultimate Mystery of Inheritance. W. W. Norton \& Company. New York, USA. 256 pp.

Funk, R.H. 2015. Endogenous electric fields as guiding cue for cell migration. Frontiers in Physiology 6(143):1-22. doi: 10.3389/fphys.2015.00143

Gilbert, S. F. 2013. Developmental Biology (Tenth Edition). Sinauer Associates, Inc. Sunderland, Massachusetts, USA.750 pp.

Godfrey-Smith, P. 2009. Darwinian Populations and Natural Selection. Oxford University Press. Oxford, England, UK. 224 pp. http://dx.doi.org/10.1093/acprof:osob1/9780199552047.001.0001

Gould, S. J. 2002. The Structure of Evolutionary Theory. The Belknap Press of Harvard University Press. Cambridge, Massachusetts, USA. 1,464 pp.

Grant, P. R. and B. R. Grant. 2009. The second contact phase of allopatric speciation in Darwin's finches. Proceedings of the National Academy of Sciences of the United States of America 106:20141-20148. http://dx.doi.org/10.1073/pnas.0911761106

Haeckel, E. 1868. Natürliche Schöpfungsgeschichte. Georg Reimer Verlag. Berlin, Germany. 568 pp. [English version entitled, The History of Creation: Or the Development of the Earth and Its Inhabitants by the Action of Natural Causes. Revised translation by Prof. E. Ray

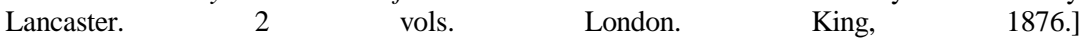
http://www.indiana.edu/ liblilly/darwin/28_HistoryOfCreation.html

Heams, T., P. Huneman, G. Lecointre, and M. Silbermeister (Editors). 2015. Handbook of Evolutionary Thinking in the Sciences. Springer, Dordrecht, The Netherlands. 910 pp. http://dx.doi.org/10.1007/978-94-017-9014-7

Jablonka, E., M. J. Lamb, and E. Avital. 1998. 'Lamarckian' mechanisms in darwinian evolution. Trends in Ecology \& Evolution 13:206-210. http://dx.doi.org/10.1016/S0169$\underline{5347(98) 01344-5}$

Jablonka, E. and M. J. Lamb. 2014. Evolution in Four Dimensions: Genetic, Epigenetic, Behavioral and Symbolic Variation in the History of Life. A Bradford Book. The MIT Press, Cambridge, Massachusetts, USA. 576 pp

Jaffe, L. F. 1981. Control of development by steady ionic currents. Federation Proceedings (Bethesda, Maryland, USA) 40:125-127. 
Jaffe, L. F. 1991. The path of calcium in cytosolic calcium oscillations: a unifying hypothesis. Proceedings of the National Academy of Sciences of the United States of America 88:98839887. http://dx.doi.org/10.1073/pnas.88.21.9883

Jaffe, L.F. 1993. Classes and mechanisms of calcium waves. Cell Calcium 14:736-745. http://dx.doi.org/10.1016/0143-4160(93)90099-R

Jaffe, L. F. and R. Nuccitelli. 1974. An ultrasensitive vibrating probe for measuring steady extracellular electric currents. Journal of Cell Biology 63:614-628. http://dx.doi.org/10.1083/jcb.63.2.614

Jaffe, L. F. and R. Nuccitelli. 1977. Electrical controls of development. Annual Review of Biophysics and Bioengineering 6:445-476. http://dx.doi.org/10.1146/annurev.bb.06.060177.002305

Jaffe, L. F. and R. Woodruff. 1979. Large electrical currents traverse developing Cecropia follicles. Proceedings of the National Academy of Sciences of the United States of America 76:1328-1332. http://dx.doi.org/10.1073/pnas.76.3.1328

Kauffmann, S.A. 1993. The Origins of Order. Self-organization and Selection in Evolution. Oxford University Press. Oxford, England, UK. 734 pp.

Kondo, H., M. Ino, A. Suzuki, H. Ishizaki, and M. Iwami. 1996. Multiple gene copies for bombyxin, an insulin-related peptide of the silkmoth Bombyx mori: structural signs for gene rearrangement and duplication responsible for generation of multiple molecular forms of bombyxin. Journal of Molecular Biology 259:926-937. http://dx.doi.org/10.1006/jmbi.1996.0370

Koonin, E. V. 2012. The Logic of Chance: The Nature and Origin of Biological Evolution. Pearson Education, Inc (FT Press Science). New Jersey, USA. 528 pp.

Koshland, D. E. 2002. The seven pillars of life. Science 292:2215-2216. http://dx.doi.org/10.1126/science.1068489

Kull K. and C. Emmeche (Editors). 2011. Towards a Semiotic Biology: Life is the action of Signs. Imperial College Press. London, England, UK. 316 pp

Laland, K., T. Uller, M. Feldman, K. Sterelny, G.B. Müller, A. Moczek, E. Jablonka, J. OdlingSmee, G.A. Wray, H.E. Hoekstra, D.J. Futuyama, R.E. Lenski, T.F. Mackay, D. Schluter, and J.E. Strassmann. 2014. Does evolutionary theory need a rethink? Nature 514:161-164. http://dx.doi.org/10.1038/514161a

Lamm, E. and R. Unger. 2011. Biological Computation. CRC Press, Taylor and Francis Publishers. Boca Raton, Florida, USA. 343 pp.

Lin, E.C., and H. F. Cantiello. 1993. A novel method to study the electrodynamic behavior of actin filaments. Evidence for cable-like properties of actin filaments. Biophysical Journal 65:1371-1378. http://dx.doi.org/10.1016/S0006-3495(93)81188-3

Logan, R. 2004. The extended mind model of the origin of language and culture. Proceedings of the Media Ecology Association. Volume 5. Rochester Institute of Technology. Rochester, New York, USA. (No pagination.)

Lovelock, J. 1995. Gaia. A New Look at Life on Earth. Oxford University Press. Oxford, England, UK. 176 pp.

Margulis, L. 1981. Symbiosis in Cell Evolution. W. H. Freeman and Company. New York, NY, USA. 452 pp.

Margulis L. and D. Sagan. 2002. Acquiring Genomes: A Theory of the Origins of Species. Basic Books, New York, USA. 256 pp.

Mayr, E. 1993. What was the evolutionary synthesis? Trends in Ecology \& Evolution 8:31-33. http://dx.doi.org/10.1016/0169-5347(93)90128-C

Mölling, K. 2015. Die Supermacht des Lebens. Reisen in die erstaunliche Welt der Viren. Stammen wir von viren ab? (The superpower of Life. Journeys in the amazing world of viruses) C. H. Beck Verlag. München, Germany. 330 pp 
Moore, D. S. 2015. The Developing Genome: An Introduction to Behavioural Epigenetics. Oxford University Press. Oxford, England, UK. 320 pp.

Müller, G. B. and S. A. Newman (Editors). 2003. Origination of Organismal Form: Beyond the Gene in Developmental and Evolutionary Biology. The Vienna Series of Theoretical Biology. A Bradford Book. The MIT Press. Cambridge, Massachusetts, USA. 322 pp.

Niemann, H-J. 2014. Karl Popper and the Two Secrets of Life: Including Karl Popper's Medawar Lecture 1986 and Three Related Texts. Mohr Siebeck Gmbh \& Co. Tübingen, Germany. 157 $\mathrm{pp}$.

Noble, D. 2015. Evolution beyond neo-Darwinism: a new conceptual framework. Journal of Experimental Biology 218(Pt1):7-13. http://dx.doi.org/10.1242/jeb.106310

Noble, D. 2013. Physiology is rocking the foundations of evolutionary biology. Experimental Physiology 98:1235-1243. http://dx.doi.org/10.1113/expphysiol.2012.071134

Noble, D. 2008. The Music of Life: Biology Beyond the Genome. Oxford University Press. Oxford, England, UK. 176 pp.

Pagel, M. D. (Editor). 2002. Encyclopedia of Evolution. Oxford University Press. Oxford, England, UK. 1326 pp.

Peixoto, L. L., M. E. Wimmer, S. G. Poplawski, J. C. Tudor, C. A. Kenworthy, S. Liu, K. Mizuno, B. A. Garcia, N. A. Zhang, K. P. Giese, and T. Abel. 2015. Memory acquisition and retrieval impact different epigenetic processes that regulate gene expression. BMC Genomics 16 Supplement 5:S5. doi: 10.1186/1471-2164-S5-S5

Pescianschi, P. 2015. Main principles of the general theory of neural network with internal feedback. The 17th International Conference on Artificial Intelligence (ICAI'15). CSREA Press. Las Vegas, Nevada. USA. http://worldcompproceedings.com/proc/p2015/ICA6229.pdf

Pescianschi, P., A. Boudichevskaia, B. Zlotin, and V. Proseanic. 2015 Analog and Digital Modeling of a Scalable Neural Network. The 17th International Conference on Artificial Intelligence (ICAI'15). CSREA Press. Las Vegas, Nevada. USA. http://worldcompproceedings.com/proc/p2015/ICA6219.pdf

Pigliucci, M. 2007. Do we need an extended evolutionary theory? Evolution 61: 2743-2749. http://dx.doi.org/10.1111/j.1558-5646.2007.00246.x

Pigliucci, M. and G.B. Müller (Editors). 2011. Evolution: The Extended Synthesis. MIT Press, Cambridge, Massachusetts, USA. 504 pp.

Pookottil, R. 2013. B.E.E.M.: Biological Emergence-based Evolutionary Mechanism: How Species Direct Their Own Evolution. Fossil Fish Publishing. London, England, UK. Distributed through Troubador Publishing Ltd. Wistow, Kibworth, Leicester, UK. 288 pp.

Raven, P., G. Johnson, K. Mason, J. Losos, and S. Singer. 2013. Biology. McGraw Hill Education. Columbus, Ohio, USA. 1,408 pp

Ridley, M. 2000. The Cooperative Gene: How Mendel's Demon Explains the Evolution of Complex Beings. The Free Press, Simon and Schuster, Inc. New York, USA.324 pp.

Rosen, R. 1991. Life Itself. A Comprehensive Enquiry into the Nature, Origin, and Fabrication of Life. Columbia University Press. New York. 285 pp.

Ruggiero, M. A., D. P. Gordon, T. M. Orrell, N. Bailly, T. Bourgoin, R. C. Brusca, T. CavalierSmith, M. D. Guiry, and P. M. Kirk. 2015. A higher level classification of all living organisms. PLoS One 10(4):e0119248. doi: 101371/journal.pone.0119248 eCollection 2015.

Ryan, F. 2009. Virolution. HarperCollins Publishers. New York, New York, USA. 400 pp.

Sapp, J. 2009. The New Foundations of Evolution: On the Tree of Life. Oxford University Press. Oxford, England, UK. 448 pp.

Schejter, A. and J. Agassi. 1994. On the definition of life. Journal for General Philosophy of Science 25:97-106. http://dx.doi.org/10.1007/BF00769279 
Shapiro, J.A. 2007. Bacteria are small but not stupid: cognition, natural genetic engineering and socio-bacteriology. Studies in History and Philosophy of Biological and Biomedical Sciences 38:807-819. http://dx.doi.org/10.1016/j.shpsc.2007.09.010

Shapiro, J. A. 2011. Evolution - A View from the 21th Century. FT Press Science. Upper Saddle River, New Jersey, USA. 272 pp.

Shapiro, J. A. 2012. Rethinking the (im)possible in evolution. Progress in Biophysics and Molecular Biology 111:92-96. http://dx.doi.org/10.1016/j.pbiomolbio.2012.08.016

Smith, K. and C. Spadafora. 2005. Sperm-mediated gene transfer. BioEssays 27:551-562. http://dx.doi.org/10.1002/bies.20211

Stebbins, G. L. and F. J. Ayala. 1981. Is a new evolutionary synthesis necessary? Science 213:967971. http://dx.doi.org/10.1126/science.213.4511.967

Telfer, W. H. and R. I. Woodruff. 2002. Ion physiology of vitellogenic follicles. Journal of Insect Physiology 48:915-923. http://dx.doi.org/10.1016/S0022-1910(02)00152-X

Thethirdwayofevolution. 2015. www.thethirdwayof evolution.com

Torday, J. S. 2013. Evolutionary biology redux. Perspectives in Biology and Medicine 56:454-484. http://dx.doi.org/10.1002/9781118130452

Torday, J. S. 2014. On the evolution of development. Trends in Developmental Biology 8:17-37.

Torday, J. S. and V. K. Rehan. 2012. Evolutionary Biology, Cell-Cell Communication, and Complex Disease. Wiley-Blackwell, John Wiley and Sons Inc. Hoboken, New Jersey, USA. 192 pp. http://dx.doi.org/10.1002/9781118130452

Trewavas, A. J. and F. Baluška. 2011. The ubiquity of consciousness, cognition and intelligence in life. EMBO Reports http://dx.doi.org/10.1038/embor.2011.218

Trewavas, A. 2014. Plant Behaviour and Intelligence. Oxford University Press. Oxford, England, UK. 304 pp. http://dx.doi.org/10.1093/acprof:oso/9780199539543.001.0001

Vane-Wright R. I. (Editor). 2014. The role of behaviour in evolution. Special Issue. Biological Journal of the Linnean Society 112:219-365. http://dx.doi.org/10.1111/bij.12300

Vertosick, F. T. 2002. The Genius Within: Discovering Intelligence of Every Living Thing. Harcourt, Inc. New York, NY, USA. 368 pp.

Villarreal, L. P. 2005. Viruses and Evolution of Life. ASM Press. Washington, District of Columbia, USA. 450 pp. http://dx.doi.org/10.1128/9781555817626

Walsh Denis, M. 2015. Organisms, Agency and Evolution. Cambridge University Press. Cambridge, England. UK. 280 pp. (in press).

West-Eberhard, M. J. 2003. Developmental Plasticity and Evolution. Oxford University Press. Oxford, England, UK. 816 pp.

Westling, L. 2014 The Logos of the Living World: Merleau-Ponty, Animals and Language. Fordham University Press. New York, USA. 209 pp.

Wheeler, W. 2006. The Whole Creature. Complexity Biosemiotics and the Evolution of Culture. Lawrence and Wishart Ltd. London, UK. 192 pp.

Williams, G. C. 1966. Adaptation and Natural Selection. A Critique of Some Current Evolutionary Thought. Princeton University Press. Princeton New Jersey, USA. 307 pp.

Witzany, G. (Editor). 2012. Viruses: Essential Agents of Life. Springer. Dordrecht, The Netherlands. 428 pp. http://dx.doi.org/10.1007/978-94-007-4899-6

Witzany, G. 2010. Biocommunication and Natural Genome Editing. Springer. Dordrecht, The Netherlands. 213 pp. http://dx.doi.org/10.1007/978-90-481-3319-2

Wolpert, L, C. Tickle, and A. Martinez Arias. 2015. Principles of Development (Fifth Edition). Oxford University Press. Oxford, England, UK. 616 pp.

Woodruff, R.I. and W. H. Telfer. 1980. Electrophoresis of proteins in intercellular bridges. Nature 286: 84-86. http://dx.doi.org/10.1038/286084a0 